\title{
Original Article \\ Perception of Patient Safety Among Final Year MBBS Students at King Edward Medical University Lahore
}

\author{
Ch. Nasir Ahmad ${ }^{1}$,Aabish Mehreen Khan ${ }^{2}$, Muhammad Awais Asghar ${ }^{3}$, Nosheen Nasir ${ }^{4}$ \\ 1 Associate Professor, Department of Ophthalmology Unit II, King Edward Medical University, Lahore \\ 2 Senior Demonstrator, King Edward Medical University, Lahore \\ 3 Department of Ophthalmology, District Head Quarter Hospital Sheikhupura \\ 4 Post Graduate Medical Institute, Lahore
}

\section{ABSTRACT}

Introduction: Patient safety is a vital part of healthcare. It is vital for the medical students that the concepts of "Do no harm" theory must be understood. Those that do not understand this ultimately perform poorly in healthcare practice. Therefore, it is very important that medical students must be tutored for the concept of good medical practice.

Objective: To assess the patient safety perception among medical students in a public sector Medical College.

Methods: A sample size of 179 medical students $(n=179)$ from final year were selected. A questionnaire tool was used to calculate the understanding of medical students. Participant's responses were recorded and computed into SPSS 19 for descriptive analysis.

Results: About 55\% participant's indicated lack in knowledge regarding patient safety.25\% of the medical students could not understand the type and nature of iatrogenic error in providing good healthcare and exercising good medical practice. Also, 57\% and $48 \%$ medical students were unable to understand that how to explain iatrogenic error to patients, their attendant and to the superiors respectively and $59 \%$ did not know that patient safety can be improved by targeted medical practice.

Conclusion: Majority of the medical students in final year MBBS were unaware of patient safety and how to improve it. However, they showed keen interest in understanding it and applying the concept of good medical practice to ensure patient safety.

KEYWORDS: Patient safety, undergraduates, knowledge, attitude.

doi: https://doi.org/10.53708/hpej.v4i1.7

This is an Open Access article is licensed under a creative commons attribution (4.0 International License).

\section{INTRODUCTION}

Patient safety is very important in the academic and clinical practice. It is vital for the medical students that the concepts of "Do no harm" theory must be understood (Simpson, Aubin, \& Fillatre, 2012). Those who do not understand this ultimately perform poorly in healthcare practice. In the past few years, many important steps have been taken to improve the situation about medical error reporting system and minimize the harm but there isn't much literature regarding patient safety perception of medical students in Pakistan (Shah, Jawaid, Shah, \& Ali, 2015) . Therefore, present study was conducted regarding patient safety perception among medical students of final year MBBS at a public sector medical college.

Absence of a well-structured system of error scrutiny in healthcare system in developing countries has raised uncertainty about the patient safety concept and the students with greater exposure to clinical activities and patients in wards have a better perception of patient safety (Shah et al., 2015). Hence, education of undergraduates in respect to patient care and safety is very important. Also, patient safety should be included as a compulsory subject/topic in the curriculum of undergraduates.

\section{Correspondence:}

Dr. Ch Nasir Ahmad,

Department of Ophthalmology Unit II, King Edward Medical University, Lahore

E-mail: drnasirch1@gmail.com,Cell:0333-4328236

Received: November 22, 2020 Accepted: March 30, 2021

Funding Source: Nil
According to WHO, Patient safety means the lack of avoidable damage and harm to the patient during health facility provision and decreasing the risk of preventable damage accompanying health system to the least that is possible (Shah et al., 2015). The World Health Organization (WHO) has lately established a detailed Patient Safety curriculum (Shah et al., 2015). This is now internationally advocated that medical student ought to be introduced the concept of patient safety in their early years so that it would lead to the fortification of the concept. It is important to know the perception of medical students about patient safety and also to assess their attitude and behavior to devise a curriculum accordingly (Armstrong, Headrick, Madigosky, \& Ogrinc, 2012).

This study is useful for medical students to improve their perception of patient safety and to achieve clinical skills and aptitude as safe doctors. So, the aim of this study was to explore the awareness of medical regarding patient safety.

\section{METHODS}

This quantitative cross-sectional study was conducted at a public sector medical college in Lahore. The target population was final year MBBS medical students (179 out of 375), as it was expected that they should have a good awareness about the patient safety. The duration of the study was one month. Formal consent from Dean was taken to carry out the study. Verbal consent was obtained from students. Discretion of data was made sure so that it should only be used for educational purposes. Data was 
collected through questionnaire. Students fulfilling the criteria were selected. A semi-structured questionnaire (Madigosky, Headrick, Nelson, Cox, \& Anderson, 2006) was prepared (consent for siting of Madigosky et. al was sought through email) and finalized by researcher for the study purpose. The responses were noted on the questionnaires.

A two-section survey form was utilized to gather the information. The initial segment was about demographic data of the participants; including age, gender. The next part comprised of 26 questions: 12 questions were structured to evaluate students' perception regarding safety of patient, involving two classifications of reasons for blunder and mistake administration, 6 questions were asked regarding undergraduates' information on patient, and 8 patient safety questions were asked regarding their outlook on involving patient safety concept in the respective institution's curriculum. A five-point Likert scale was utilized for gauging recognitions and states of mind of the participants.

Institutional Review Board (IRB) authorization was obtained from University of Lahore (UOL). The said study was conducted in agreement with the Declaration of Helsinki. No damage to the undergraduates was expected to happen. The students were guaranteed that their responses would remain private. After a formal informed consent and proper counseling, the questionnaire with the perspective of patient safety was given to the participants. This was carried out in the classroom, immediately after the scheduled lecture. The principal investigator with Class-Representative (CR) and two lecture hall attendants circulated the questionnaire.

Responses from the participants were recorded and computed into SPSS 19. Descriptive analysis was carried out. A nonresponder was defined as a student who failed to return a completed questionnaire proforma. For numerical facts, mean and standard deviation was employed. For categorical data, percentage and frequencies were considered. Pearson correlation coefficients were computed to evaluate the item total score correlation. Cronbach coefficient alpha was calculated to measure the internal consistency aspect of dependability of the instrument. A p-value of $<0.05$ was taken into consideration to indicate statistical significance.

\section{RESULTS}

A total of 174 of 179 medical students responded to the survey (97\% response rate). Fifty three students(30.11\%) were male and 126 (69.89\%) were females as shown in Figure-1.

$25 \%$ of the medical students could not understand the type and nature of iatrogenic error in providing good healthcare and exercising good medical practice. Also, 57\% and $48 \%$ medical students were unable to understand that how to explain iatrogenic error to patients, their attendant and to the superiors respectively and 59\% did not know that patient safety can be improved by targeted medical practice. Spearman rank correlation coefficient was used to find out the relationship between variable that gauge patient safety while ANOVA was used to relate the mean values of the students' perception, information and attitude as mentioned in table 1 .

\section{Male/Female Ratio}

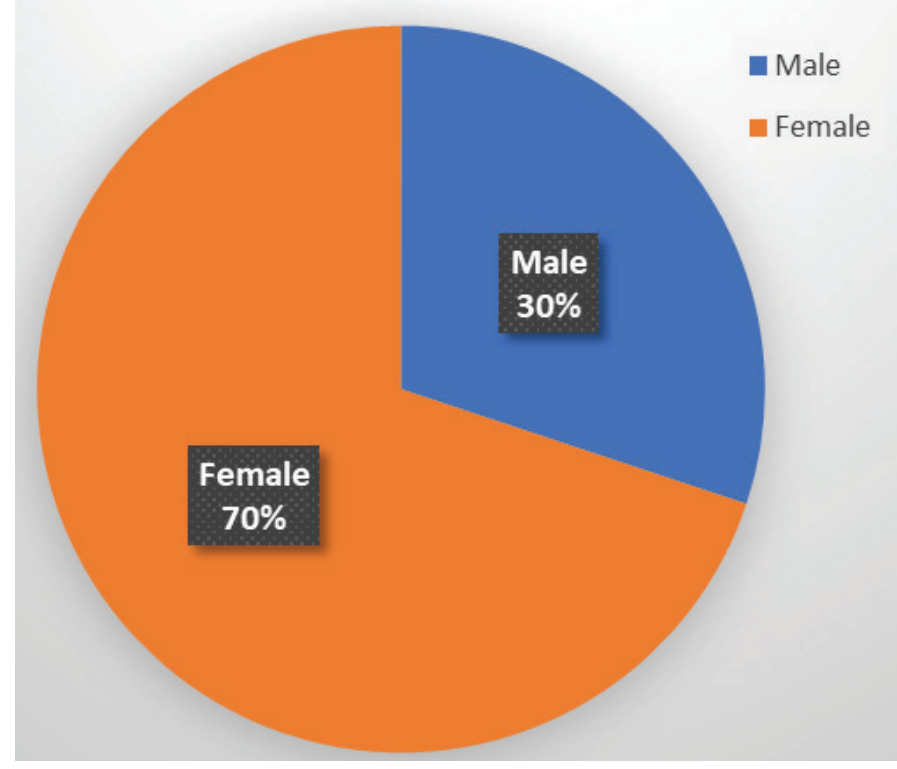

Fig I: Male / Female ratio showing lack in knowledge regarding patient safety.

\section{DISCUSSION}

Patient safety is an integral part of medical field. Having good concepts of patient safety improves professionalism and competency of health (Lewis, Vaithianathan, Hockey, Hirst, \& Bagian, 2011).

As per importance of the patient safety concept, it should have been addressed as a compulsory subject/topic, but unfortunately, on undergraduate level, not much emphasize is given to the said subject resulting in overall low perception, knowledge and application of patient safety concept. Multiple studies have been done to cover the boundaries of patient safety and wellbeing and to evaluate the insight regarding concept of patient safety among healthcare professionals, medical and allied healthcare undergraduates around the world. These studies conducted in the past showed that perception of patient safety concept varies from institution to institution, specialty to specialty and person to person (Armstrong et al., 2012). Lately, a study conducted in United Kingdom reflected that undergraduate medical students had limited knowledge about error reporting and didn't know what and how to do it, if a fellow student makes a mistake or if a patient claims that a medical error has happened (Nabilou, Feizi, \& Seyedin, 2015).Our study raised few important aspects such 
Table I: Perception, Information and attitude of students

\begin{tabular}{|c|c|c|c|c|c|c|}
\hline $\begin{array}{l}\text { Attitude } \\
\text { items }\end{array}$ & & $\begin{array}{c}\text { Strongly } \\
\text { agree }\end{array}$ & Agree & Neutral & Disagree & $\begin{array}{l}\text { Strongly } \\
\text { Disagree }\end{array}$ \\
\hline \multirow{4}{*}{$\begin{array}{l}\text { Causes of } \\
\text { Errors }\end{array}$} & Making errors in healthcare is unavoidable & 14.5 & 40.3 & 15 & 24.6 & 5.6 \\
\hline & $\begin{array}{l}\text { Difference between what doctors label as "best } \\
\text { care" and what is being provided on an } \\
\text { everyday basis }\end{array}$ & 15.8 & 55.8 & 9.7 & 14.5 & 4.2 \\
\hline & $\begin{array}{l}\text { Capable doctors do not make such medical } \\
\text { errors }\end{array}$ & 5.9 & 24.8 & 20.9 & 44.2 & 4.2 \\
\hline & Factors that are out of doctors' hand & 18.2 & 55.6 & 2.9 & 20.1 & 3.2 \\
\hline \multirow{8}{*}{$\begin{array}{l}\text { Error } \\
\text { Management }\end{array}$} & $\begin{array}{l}\text { If I witnessed a medical error, I would quiet } \\
\text { about it }\end{array}$ & 37 & 26.3 & 24.1 & 9.7 & 2.9 \\
\hline & $\begin{array}{l}\text { Error not causing damage to the patient, No } \\
\text { need to rectify it. }\end{array}$ & 11.8 & 16.7 & 6 & 56.4 & 9.1 \\
\hline & $\begin{array}{l}\text { Doctors can evaluate the causes of a medical } \\
\text { error }\end{array}$ & 5.4 & 21.3 & 9.4 & 33.8 & 30.1 \\
\hline & $\begin{array}{l}\text { Reporting systems play small role to reduce } \\
\text { future errors }\end{array}$ & 9.6 & 8.3 & 17.1 & 52 & 13 \\
\hline & $\begin{array}{l}\text { An efficient approach is to do better be more } \\
\text { cautious }\end{array}$ & 35.1 & 46.1 & 8.2 & 8.3 & 2.3 \\
\hline & $\begin{array}{l}\text { Doctors ought not to overlook ambiguity in } \\
\text { patient care }\end{array}$ & 10.2 & 55.1 & 12.8 & 20.9 & 1 \\
\hline & $\begin{array}{l}\text { The environment of healthcare system makes it } \\
\text { convenient for caregivers to deal positively } \\
\text { with errors }\end{array}$ & 7.5 & 44.2 & 30.9 & 14.4 & 3 \\
\hline & Doctors report medical errors on a regular basis & 3.2 & 16.7 & 12.7 & 46.1 & 11.3 \\
\hline \multirow{4}{*}{ Education } & $\begin{array}{l}\text { Doctors should habitually offer part of their } \\
\text { professional time trying to make patient care } \\
\text { better }\end{array}$ & 23.1 & 59.5 & 9.2 & 7 & 1.2 \\
\hline & 'Patient safety' is a vital topic & 28.2 & 57.6 & 5.1 & 9.1 & 0 \\
\hline & $\begin{array}{l}\text { Learning how to make patient safety better is a } \\
\text { fitting expenditure of time in medical school }\end{array}$ & 18.8 & 53.8 & 9.1 & 17.3 & 1 \\
\hline & $\begin{array}{l}\text { You would be interested in acquiring further } \\
\text { knowledge on patient safety }\end{array}$ & 7.9 & 50.2 & 25.8 & 14 & 2.1 \\
\hline \multirow{4}{*}{ Skills } & $\begin{array}{l}\text { Supporting and counseling a colleague who } \\
\text { must decide how to tackle an error }\end{array}$ & 14 & 47.3 & 22.5 & 10 & 6.2 \\
\hline & $\begin{array}{l}\text { Supporting and counseling a colleague who } \\
\text { must decide how to analyze a case to reach the } \\
\text { cause of an error }\end{array}$ & 10.2 & 57.6 & 18 & 9.7 & 4.5 \\
\hline & $\begin{array}{l}\text { Supporting and counseling a colleague who } \\
\text { must decide how to reveal an error to a patient. }\end{array}$ & 5.3 & 39.8 & 9.8 & 29.6 & 15.5 \\
\hline & $\begin{array}{l}\text { Supporting and counseling a colleague who } \\
\text { must decide how to disclose an error to a } \\
\text { faculty member. }\end{array}$ & 20.2 & 48.6 & 19 & 10.2 & 2 \\
\hline
\end{tabular}

as limited knowledge about patient safety (45\%) and practical application of patient safety concept. While dealing with the medical errors, when inquired about the causes of medical errors, many participants (40\%) reflected that medical errors are unavoidable, and that human error does play a vital role in providing best healthcare to the patients. Such misconceptions regarding patient safety and healthcare provision were in correlation with studies conducted by Bahram, Aram and Hesam (Nabilou et al., 2015).When dealing with error management, multiple aspects were considered like error reporting system, near-miss concept, determination of cause of error, good strategy plan and bearing the uncertainty and cultural limitations of healthcare provision. All the aspects were in line with the studies done by Bahram, Aram and Hesam (Nabilou et al., 2015).

As far as the knowledge about patient safety is concerned, students visiting clinical wards during official and non-official timings, were significantly better in perception of patient safety, thus confirming that spending more time on bedside of patient 
Table II: Relationship between patient's safety and knowledge of students

\begin{tabular}{|c|c|c|c|c|c|c|}
\hline \multirow{6}{*}{$\begin{array}{l}\text { Knowledge } \\
\text { Items }\end{array}$} & $\begin{array}{l}\text { The amount of avoidable unfavorable } \\
\text { proceedings each year in Health care } \\
\text { commission }\end{array}$ & 1.3 & 16.6 & 40.2 & 39.9 & 2 \\
\hline & $\begin{array}{l}\text { The amount of avoidable unfavorable } \\
\text { proceedings each year reported by international } \\
\text { bodies, e.g., IOM Report: To Err is Human }\end{array}$ & 4 & 20.2 & 35.5 & 33.2 & 7.1 \\
\hline & $\begin{array}{l}\text { Approximate percentage of hospital admissions } \\
\text { with unfavorable occurrences }\end{array}$ & 2.6 & 30.1 & 29.6 & 31.2 & 6.5 \\
\hline & Features of a reliable error reporting system & 1 & 20.2 & 33,9 & 37.5 & 7.4 \\
\hline & Definition of latent factors & 7.2 & 11.1 & 23 & 42.6 & 16.1 \\
\hline & You are well educated on 'patient safety' & 4.6 & 27.4 & 39.1 & 25.4 & 3.5 \\
\hline
\end{tabular}

has a beneficial role for the patient safety concept (Berwick, Shojania, \& Atchinson, 2015). Similar results were reported by Hamdi, Hani and Kamal in Saudi Arabia (Almaramhy, AlShobaili, El-Hadary, \& Dandash, 2011).

Overall, the participants (85\%) showed a positive attitude towards the concept of patient safety (p-value $<0.05$ ) and emphasized on the necessity of learning about patient safety. Leung also showed that most of the participants stressed the importance of tutoring patient safety, basic coaching skills and time allotment to the relevant courses (Organization, 2017). Bowman also indicated the significance of student's concern for training about patient safety (Organization, 2017). Patey and Abidi both stated that the lack of sufficient knowledge and negative approach of medical students during pre-clinical phase (Patey et al., 2007). It is important to consider that participants in this study were from a single institution. Multi-institutional studies can provide a better picture about the awareness of medical students about the patient safety.

\section{CONCLUSION}

The medical students of final year MBBS were familiar with the basic knowledge and concept regarding patient safety though majority lacked knowledge about occurrence of medical error and how to act after an error. Patient safety concept should be made a part of the syllabus of undergraduates, also multiple workshops and activity sessions should be organized to facilitate and enhance the learning of patient safety concept, which will certainly improve patient care.

\section{DECLARATION OF INTEREST}

The author report no declaration of interest.

\section{REFERENCES}

Almaramhy, H., Al-Shobaili, H., El-Hadary, K., \& Dandash, K. (2011). Knowledge and attitude towards patient safety among a group of undergraduate medical students in Saudi Arabia. International journal of health sciences, 5(1), 59.

Armstrong, G., Headrick, L., Madigosky, W., \& Ogrinc, G. (2012). Designing education to improve care. The Joint Commission journal on quality and patient Safety, 38(1), 5-AP2.

Berwick, D., Shojania, K., \& Atchinson, B. (2015). Free from harm: Accelerating patient safety improvement fifteen years after To Err Is Human. Boston, MA National Patient Safety Foundation.

Lewis, G. H., Vaithianathan, R., Hockey, P. M., Hirst, G., \& Bagian, J. P. (2011). Counterheroism, common knowledge, and ergonomics: concepts from aviation that could improve patient safety. The Milbank Quarterly, 89(1), 4-38.

Madigosky, W. S., Headrick, L. A., Nelson, K., Cox, K. R., \& Anderson, T. (2006). Changing and sustaining medical students' knowledge, skills, and attitudes about patient safety and medical fallibility. Academic Medicine, 81(1), 94-101.

Nabilou, B., Feizi, A., \& Seyedin, H. (2015). Patient safety in medical education: students' perceptions, knowledge and attitudes. PloS one, 10(8), e0135610.

Organization, W. H. (2017). Patient safety: making health care safer: World Health Organization.

Patey, R., Flin, R., Cuthbertson, B. H., MacDonald, L., Mearns, K., Cleland, J., \& Williams, D. (2007). Patient safety: helping medical students understand error in healthcare. BMJ Quality \& Safety, 16(4), 256-259. 
Shah, N., Jawaid, M., Shah, N., \& Ali, S. M. (2015). Patient safety: perceptions of medical students of dow medical college, Karachi. J Pak Med Assoc, 65(12), 1261-1265.

Simpson, C., Aubin, D., \& Fillatre, T. (2012). The ethics of disclosure of patient safety incidents. Paper presented at the Healthcare management forum.

\section{AUTHOR'S CONTRIBUTION}

1. Ch. Nasir Ahmad: Conception and design of the work and the aquisition, analysis \& interpretation of data for the work.

2. Aabish Mehreen Khan: Analysis and interpretation of data.

3. Muhammad Awais Asghar: Analysis and interpretation of data.

4. Nosheen Nasir: Critical review and final approval of the version to be published 